\title{
PURIFICATION SYSTEM FOR ROOF WATER HARVESTING
}

\author{
${ }^{1}$ Swatha, V.S.; ${ }^{2}$ Dr. Sathian, K.K. \\ ${ }^{1,2}$ Dept of Land and Water Resources Conservation \\ Engineering, Kerala Agricultural University.
}

DOI: 10.46609/IJAER.2020.v06i03.002 URL: https://doi.org/10.46609/IJAER.2020.v06i03.002

\begin{abstract}
Due to the filter clogging, majority of the roof water harvesting systems are dysfunctional after a very short span of life of their commissioning. In this context, an alternative filter system with high filtration efficiency and easy to clean provision will be a great boon in solving the roof water harvesting issue. The upward flow mesh filter is the solution; it can be made in different mesh sizes. The existing one is 100 micron mesh filter and its filtration efficiency is found to be 84.6\%. For improving the efficiency of the system, 60, 40 and 25 micron mesh filter has been designed and has been compared with the 100 micron mesh filter. It is found that by using 60, 40 and 25 micron mesh filter, efficiency is increased to $86.2 \%, 87.53 \%$ and $88.4 \%$. As part of the study, quality of roof water from different kinds of roofing materials has been conducted and the parameters viz. pH, EC, TDS, suspended matters and microbial content have been evaluated.
\end{abstract}

Keywords: Roof water harvesting system, First flush system, Mesh filter

\section{INTRODUCTION}

The importance of water is obvious to everyone. We cannot imagine existence of life in the form of flora and fauna without water. At present space scientists are vigorously engaged in searching for water on other planets. Existence of life on other planets is not conceivable for the human mind, unless there is evidence of water. Rainwater harvesting promotes self-sufficiency and fosters an appreciation for water as a resource. It saves money, saves other sources of water, reduces erosion and storm water runoff and increases water quality. Rainwater can provide clean, safe and reliable water for drinking so long as the collection and purification system is properly designed and constructed and maintained appropriately for its intended use. Rainwater harvesting means capturing rain where it falls or capturing the runoff in a village or town and taking all precautions to keep it unpolluted. . Hence, the most effective way to obtain fresh drinking water is to harvest rainwater. The quality of harvested rainwater depends upon many factors such as air 
International Journal of Agriculture and Environmental Research

ISSN: 2455-6939

Volume: 06, Issue: 03 "May-June 2020"

quality, system design and maintenance, materials used, rainfall intensity, length of time between rainfall events, social context as well as water handling. Rainwater is usually the cleanest available water source (Gonçalves et al., 2003) and rainwater harvesting is one of the best methods available for establishing sustainable water cycles in urban development's (Lye, 2009). Roofs are the most ideal catchments for RWH systems because their runoff is often regarded as unpolluted (Forster, 1999). However, some studies have reported that there is a potential for rainwater to carry nutrient pollution (total phosphorus and nitrate nitrogen) (Vijayaraghavanet al., 2012), microbial pathogens (Ahmed et al., 2008; Simmons et al., 2001), heavy metals (Lee et al., 2010; Wang and Li, 2009) and pesticides (Zobrist et al., 2000). Due to rapid economic development and consequent increase in energy consumption, concerns about air pollution have emerged to be an important social and scientific issue in developing countries. So an efficient filter system is essential for every roof water harvesting systems. Rainwater is the most effective scavenging factor for removing particulate and dissolved organic gaseous pollutants from the atmosphere.

The main objective of the study reported herein was to design and develop a more efficient and hassle free filter system with an appropriate first flush system for domestic roof water harvesting.

\section{MATERIALS AND METHODS}

The details of the design, construction and evaluation of various filters for roof water harvesting systems are presented in this chapter.

\subsection{Study Area}

Study has been conducted on the existing micro mesh filter and the newly developed filter in the campus of Kelappaji College of Agricultural Engineering and Technology (KCAET), Tavanur, Malappuram, Kerala, India. Geographical reference of the study area is $10^{\circ} 51^{\prime} 20^{\prime \prime} \mathrm{N}$ latitude and $75^{\circ} 59^{\prime} 5^{\prime \prime}$ E longitude. Average annual rainfall of the area for the last 30 years is $294 \mathrm{~cm}$. About $75 \%$ of the annual rainfall is received through South West monsoon (June to September) and the balance $25 \%$ is through North East Monsoon (October to November) and summer rains (December to May). The summer rain is very meagre with a usual variation of $0-5 \%$.

\subsection{Working of filter systems}

Rainwater coming down from the rooftop through the collector system is conveyed to the filter through a $63 \mathrm{~mm}$ pipe which then enters into the first flushing tank having 18 litre capacity. From this flust flushing tank most of the impurities present in the roof water will settle down. Impurities settled at the bottom can be removed by manually. As the water level rises in the first 
flush diverter chamber the ball floats, and once the chamber is full, the ball rests on a seat inside the diverter chamber preventing any further water entering the diverter. The subsequent flow of water is then automatically directed along a $90 \mathrm{~mm}$ pipe where the incoming flow velocity is reduced and the debris are allowed for initial settlement. Then, the rainwater with reduced velocity of flow move upward through the annular space between the casing pipe and the filter element. Water then passes through the micro mesh of the filter where removal of suspended particles takes place. The filtered water then moves to the storage tank. The entire movement of water from the roof to the storage tank takes place under gravity force without expending any additional energy. As the micro mesh filter unit is designed for the pass of water in upward direction, some of the suspended particles is settled at the bottom of its annular space and will reduce the load of impurities for the mesh filter. Impurities settled at the bottom can be removed by opening the end cap provided at the bottom by flushing.

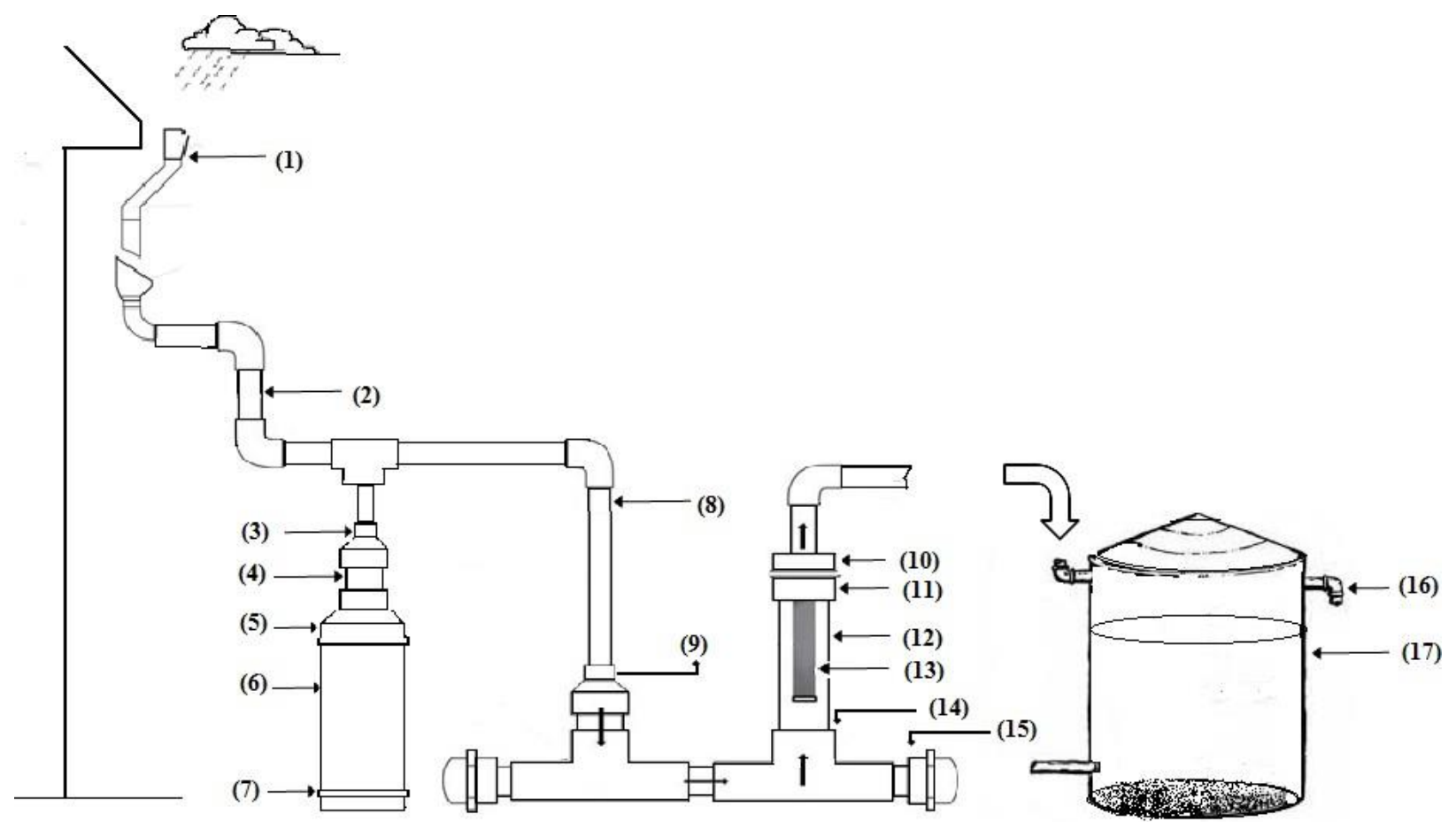

Fig. 2.1: Upward flow filter with first flush system
(1) Gutter
(6) $160 \mathrm{~mm}$ PVC
(11) $90 \mathrm{~mm}$ MTA
(16) Overflow pipe
(2) $63 \mathrm{~mm} \phi \mathrm{PVC}$ pipe
(7) $160 \mathrm{~mm}$ End cap
(12) $90 \mathrm{~mm} \phi$ PVC pipe
(17) storage tank
(3) $110 \times 63 \mathrm{~mm}$ Connector
(8) $63 \mathrm{~mm} \phi \mathrm{PVC}$
(13) Filter element
(4) $110 \mathrm{~mm} \Phi$ PVC pipe
(9) $90 \times 63 \mathrm{~mm}$ Connector
(14) $90 \mathrm{~mm} \mathrm{~T}$ joint Connector
(5)160x110mm Connector
(10) $90 \mathrm{~mm}$ End cap
(15) $90 \mathrm{~mm}$ End cap 


\subsection{Estimation of water quality parameters}

The quality of filtered water is mainly assessed to know the potability of the roof water. Water quality parameters obtained through the test were compared with that of the threshold levels as specified by WHO and BIS.

\subsubsection{Physical analysis through water quality analyzer}

A water quality analyzer, systronics water quality analyser 371 was used to carry out the physical analysis of the roof water. It is a micro controller based instrument for measuring $\mathrm{pH}$, dissolved oxygen, salinity, conductivity, TDS, temperature, colorimetric and turbidity in water sample one at a time. The analyser provides both automatic and manual temperature compensation. The important physical parameters include $\mathrm{pH}$, electrical conductivity, TDS of the rainwater collected from roof samples were tested.

\subsubsection{Total suspended solids by gravimetric method}

The suspended solids consist of inorganic matter like sand and organic matter like moss. For measuring suspended solids, the water is filtered through a fine filter (wattmann no.1) and the dry material retained on the filter is weighed. The drying was carried out at room temperature.

Total suspended solids in $\mathrm{g} / \mathrm{l}=\frac{w 2-w 1}{v} \times 1000$

Where,

$\mathrm{W} 1=$ Initial weight of filter paper, $\mathrm{g}$

W2 = Weight of filter paper and the dry material retained on the filter, $\mathrm{g}$

$\mathrm{V} \quad=$ Volume of sample, $\mathrm{ml}$

\subsubsection{Metal concentration}

The tests were undertaken at the Radio Tracer Laboratory of Kerala Agricultural University. A total of 8 metals were analyzed in the harvested rainwater, including $\operatorname{copper}(\mathrm{Cu}), \operatorname{zinc}(\mathrm{Zn})$, iron $(\mathrm{Fe})$, manganese $(\mathrm{Mn})$, calcium $(\mathrm{Ca})$, magnesium $(\mathrm{Mg})$, sodium(Na), pottasium(K).

\subsubsection{Microbiological parameters}

To determine the suitability of harvested rainwater as a source of drinking water, the samples were tested for bacteria, fungi, actinomycetes and E.coli analysis. 


\subsection{Estimation of filter efficiency by suspended solids}

The efficiency of the filters has been determined by the following equation.

$$
E=\frac{S_{b}-S_{a}}{S_{b}} \times 100
$$

Where,

$\mathrm{E}=$ Efficiency of the filter, \%

$\mathrm{Sb} \quad=$ Suspended solids before filtering, $\mathrm{mg} / \mathrm{l}$

$\mathrm{Sa} \quad=$ Suspended solids after filtering, $\mathrm{mg} / \mathrm{l}$

\section{RESULTS AND DISCUSSION}

\subsection{Estimation of water quality parameters}

\subsubsection{Physical analysis through water quality analyzer}

The $\mathrm{pH}$ of roof water collected from different buildings with different roofing materials is evaluated. $\mathrm{pH}$ values of the roof water samples collected from three different roofs with two concentrations and it passing through four different filters. The values are ranging from 6.8 to 7.4. The water will not cause any health problems. Variation in roofing material cause changes to the $\mathrm{pH}$ values. Asbestos shows a small acidic behavior but tile and concrete provide roof water that is slightly alkaline in nature. The use of first flush system also shows a small change in acidic behavior and alkaline behavior.

EC of collected water samples of different roofing materials which were passed through the four different filter sizes. The EC values ranges between 85 to $189 \mu \mathrm{S} / \mathrm{cm}$. The values showed that the outflow through the filters have slightly less EC. While comparing the EC values for different roofing materials, it is noted that tiled roof has less EC. First flush system with 25 micron filter shows more reduction in EC values. Variations in EC may be due to the varied presence of charged ions in the impurities in the atmosphere and on the roof.

The TDS values were ranging from 48.13 to $66.25 \mathrm{ppm}$. Compared to inflow, the TDS values of outflow were marginally lower. According to IS 10500-1991 desirable limit of TDS is 500ppm. The TDS value is within permissible limit and hence, the water is potable.

\subsubsection{Total suspended solids by gravimetric method}


Total suspended solids were calculated and are presented in table 4.7. The desirable limit of TSS recommended for drinking water by WHO is $500 \mathrm{mg} / \mathrm{l}$. The results showed that the TSS of the water samples is within the desirable limit.

\subsubsection{Metal concentration}

The tests were undertaken at the Radio Tracer Laboratory of Kerala Agricultural University. A total of 8 metals were analyzed in the harvested rainwater, including copper $(\mathrm{Cu}), \operatorname{zinc}(\mathrm{Zn})$, iron $(\mathrm{Fe})$, manganese $(\mathrm{Mn})$, calcium( $\mathrm{Ca})$, magnesium $(\mathrm{Mg})$, $\operatorname{sodium}(\mathrm{Na}), \operatorname{potassium}(\mathrm{K})$.
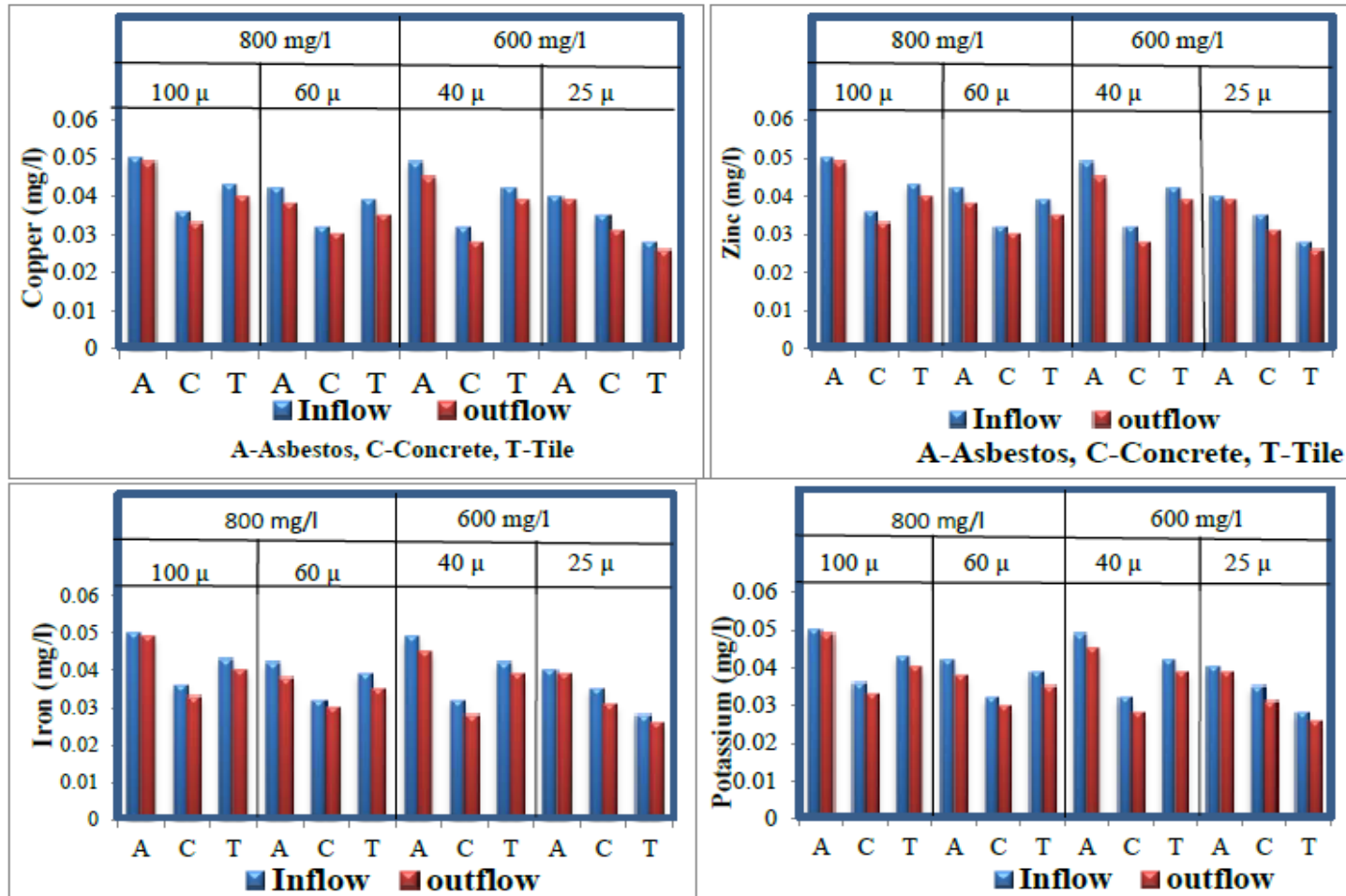

A-Asbestos, C-Concrete, T-Tile

A-Asbestos, C-Concrete, T-Tile

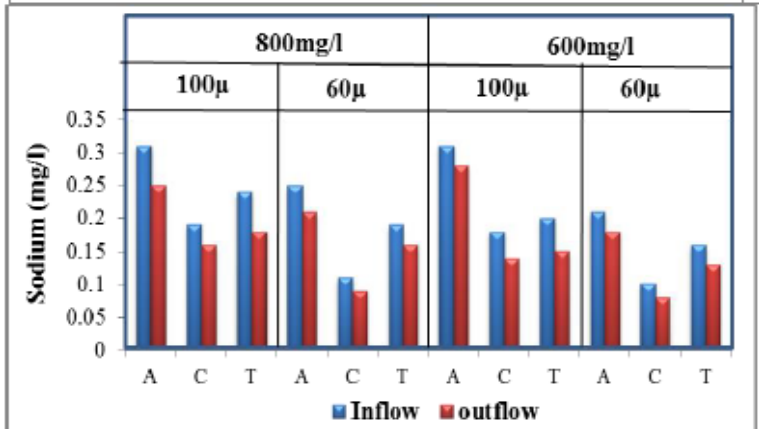

A-Asbestos, C-Concrete, T-Tile

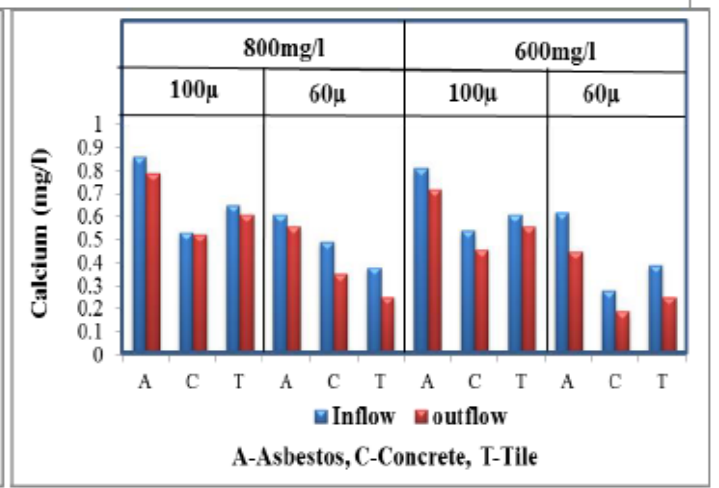


International Journal of Agriculture and Environmental Research

ISSN: 2455-6939

Volume: 06, Issue: 03 "May-June 2020"
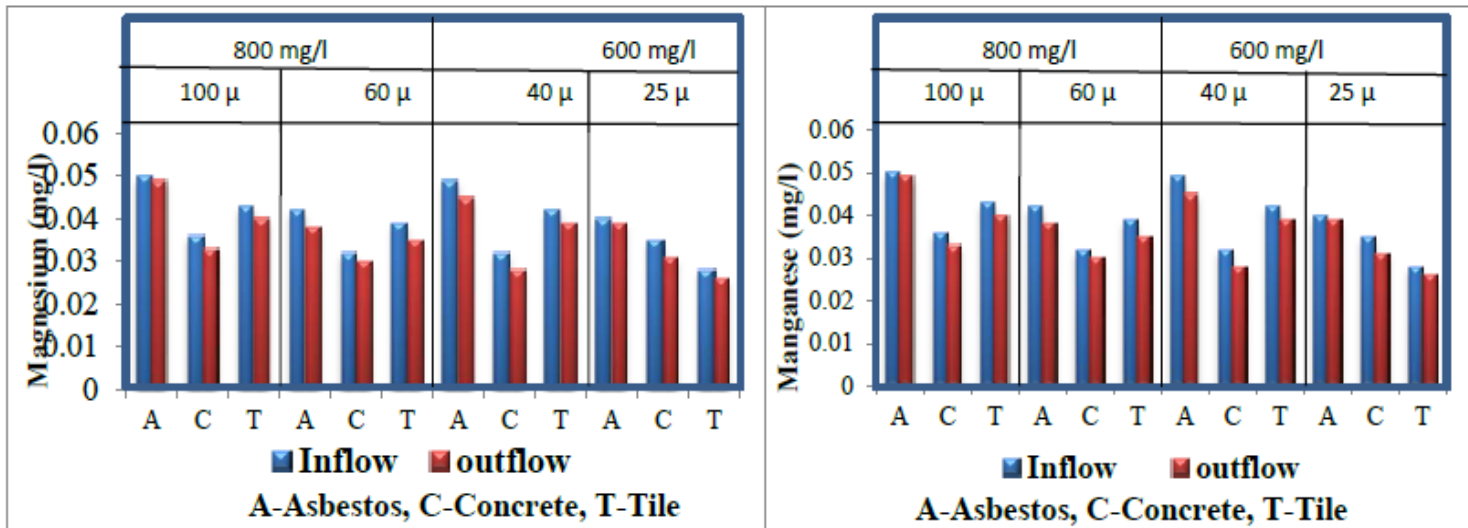

Fig. 3.1: Metal concentration on water samples

\subsubsection{Microbiological parameters}

To determine the suitability of harvested rainwater as a source of drinking water, the samples were tested for bacteria, fungi, actinomycetes and E.coli analysis.

Table 3.1: Microbial concentration of water samples

\begin{tabular}{|c|c|c|c|c|c|c|}
\hline $\begin{array}{l}\text { Mesh } \\
\text { size }\end{array}$ & $\begin{array}{l}\text { Roofing } \\
\text { materials }\end{array}$ & Inflow/Outflow & $\begin{array}{c}\text { Bacteria } \\
\left(10^{5} \mathrm{cfu} / \mathrm{ml}\right)\end{array}$ & $\begin{array}{c}\text { Fungi } \\
\left(10^{2} \mathrm{cfu} / \mathrm{ml}\right)\end{array}$ & $\begin{array}{c}\text { Actinomycetes } \\
\left(10^{3} \mathrm{cfu} / \mathrm{ml}\right)\end{array}$ & $\begin{array}{l}\text { E.coli } \\
\text { count }\end{array}$ \\
\hline \multirow{6}{*}{100} & \multirow{2}{*}{ Asbestos } & Inflow & 83 & 5 & 4 & 0 \\
\hline & & Outflow & 30 & 2 & 2 & 0 \\
\hline & \multirow{2}{*}{ Concrete } & Inflow & 123 & 2 & 7 & 0 \\
\hline & & Outflow & 107 & 1 & 4 & 0 \\
\hline & \multirow[t]{2}{*}{ Tile } & Inflow & 94 & 5 & 5 & 0 \\
\hline & & Outflow & 91 & 3 & 3 & 0 \\
\hline \multirow{6}{*}{60} & \multirow{2}{*}{ Asbestos } & Inflow & 76 & 3 & 3 & 0 \\
\hline & & Outflow & 62 & 1 & 2 & 0 \\
\hline & \multirow{2}{*}{ Concrete } & Inflow & 73 & 5 & 4 & 0 \\
\hline & & Outflow & 38 & 1 & 2 & 0 \\
\hline & \multirow[t]{2}{*}{ Tile } & Inflow & 62 & 3 & 2 & 0 \\
\hline & & Outflow & 48 & 1 & 1 & 0 \\
\hline \multirow{6}{*}{40} & \multirow[t]{2}{*}{ Asbestos } & Inflow & 28 & 2 & 1 & 0 \\
\hline & & Outflow & 22 & 1 & 0 & 0 \\
\hline & \multirow{2}{*}{ Concrete } & Inflow & 49 & 3 & 3 & 0 \\
\hline & & Outflow & 36 & 0 & 0 & 0 \\
\hline & \multirow[t]{2}{*}{ Tile } & Inflow & 35 & 1 & 2 & 0 \\
\hline & & Outflow & 29 & 0 & 0 & 0 \\
\hline & \multirow[t]{2}{*}{ Asbestos } & Inflow & 18 & 1 & 1 & 0 \\
\hline & & Outflow & 9 & 0 & 0 & 0 \\
\hline
\end{tabular}


International Journal of Agriculture and Environmental Research

ISSN: 2455-6939

Volume: 06, Issue: 03 "May-June 2020"

\begin{tabular}{|c|c|c|c|c|c|c|}
\hline \multirow{3}{*}{25} & \multirow{3}{*}{ Concrete } & Inflow & 22 & 3 & 1 & 0 \\
\cline { 3 - 7 } & & Outflow & 20 & 0 & 0 & 0 \\
\cline { 2 - 7 } & \multirow{2}{*}{ Tile } & Inflow & 20 & 1 & 1 & 0 \\
\cline { 3 - 7 } & Outflow & 17 & 0 & 0 & 0 \\
\hline
\end{tabular}

\subsection{Estimation of filter efficiency by suspended soilids}

Filtration efficiency of the two filters is calculated and is shown in the tables. The average efficiency has also been tabulated. The results showed that the average efficiency of the $25 \mu$ mesh filter is more than that of a $100 \mu, 60 \mu$ and $40 \mu$ mesh filters.

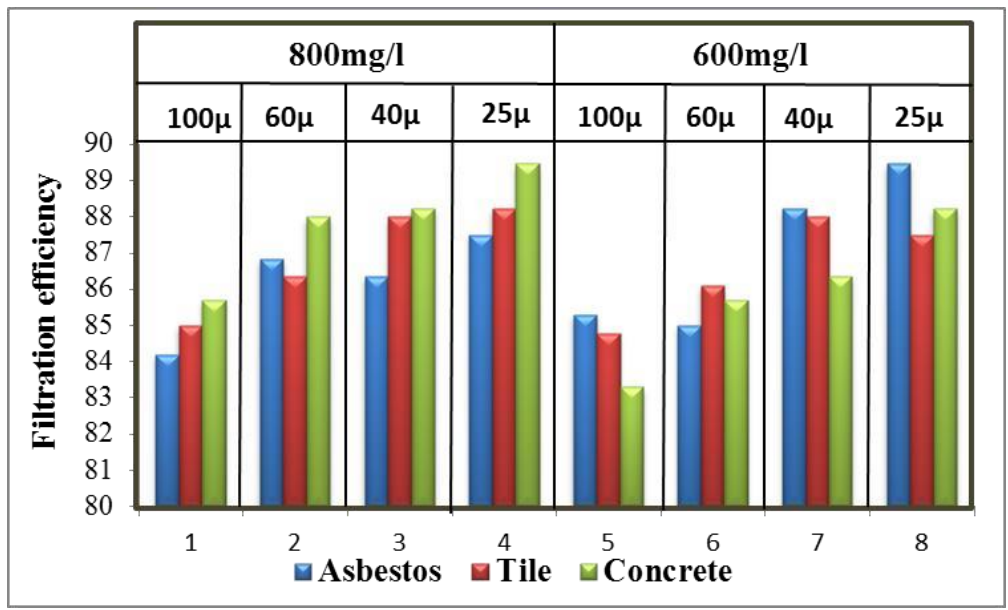

Fig. 3.2: Filtration efficiency of filters

\section{CONCLUSION}

From this study, the efficiency of the 25 micron filter is high with a value of $88.4 \%$. First flush system is found to be effective in removing the higher concentration of impurities from the initially generated roof water. First flush system along with $25 \mu$ filter is found to be more effective in purifying the roof water, compared to other mesh filter.

\section{REFERENCES}

Ahammed, M. M. and Meera,V. 2006. Iron hydroxide-coated sand filter for household drinking water from roof- harvested rainwater. J. Water Supply Res. and Technol.- Aqua. 55: 493-498.

Anirban, K. And Niranjali, J. 2010. Optimal sizing of rain water tanks for domestic water conservation. J. Hydrol. 381(3-4) 181-188. 
Boers, T. M. 1994. Rainwater harvesting in arid and semi-arid zones. International Institute for Land Reclamation and Improvement, Wageningen, Netherlands.

Evans, C. A., Coombes, P. J., and Dunstan, R. H. 2006. Wind, rain and bacteria: The effect of weather on the microbial composition of roof-harvested rainwater. J. Water Res40: 37 44.

Fayez, A. A. and Al-Shareef, A. W. 2009. Roof rainwater harvesting systems for household water supply in Jordan. Desalination. 243: 195-207.

Kus, B., Kandasamy, J., Vigneswaran, S., and Shon, H. K. 2010. Analysis of first flush to improve the water quality in rainwater tanks. Water Science and Technology. 61(2): 421428.

Luke, M. 2005. Water quality of rainwater harvesting systems. SOPAC Miscellaneous Report. $579 \mathrm{p}$.

Ronan, F. M. N., Maria, L. C., Isabella de, C. C., and Aníbal da, F. S. 2012. Rainwater treatment in airports using slow sand filtration followed bychlorination: efficiency and costs. J. Resour., Conserv. and Recycling 65: 124- 129.

Sharma,S. K. 1999. Roof - top rainwater harvesting technique in an urban area - a case study from India. Geological Research Institute 24 National Road, Dehradun 248001, India.

Vincenzo, N., Davide, S., and Belgiorno, V. 2013. Enhanced drinking water supply through harvested rainwater treatment. J. Hydrol.498: 287-291.

Visalakshi, K. P., Reena, M., and Raneesh, K. Y. 2006. Rain water harvesting in KAU - a safe guard against the water crisis of the campus, Kerala, India . pp. 05-41.

Ward, S., Memon, F. A., and Butler, D. 2004. Harvested rainwater quality: the importance of appropriate design. Water Science \& Technology. 61(7): 1707-1714. 